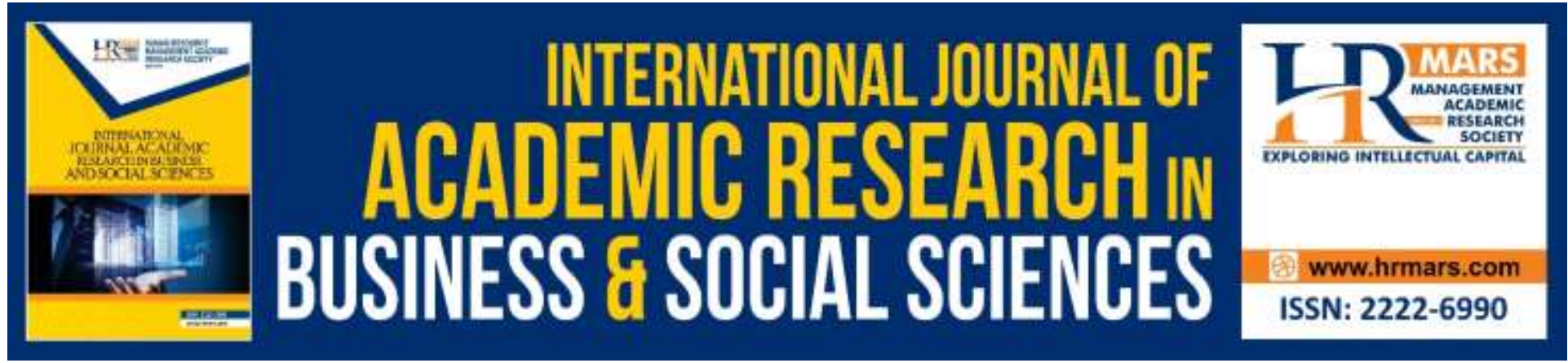

\title{
Information and Communication Technology (ICT) and Income Inequality in ASEAN-5 Countries
}

\author{
Amy Huong Yong Jing, Rossazana Ab-Rahim \& Farhana Ismail
}

To Link this Article: http://dx.doi.org/10.6007/IJARBSS/v9-i9/6303

DOI: $10.6007 /$ IJARBSS/v9-i9/6303

Received: 08 July 2019, Revised: 19 August 2019, Accepted: 30 August 2019

Published Online: 09 September 2019

In-Text Citation: (Jing, Ab-Rahim, \& Ismail, 2019)

To Cite this Article: Jing, A. H. Y., Ab-Rahim, R., \& Ismail, F. (2019). Information and Communication Technology (ICT) and Income Inequality in ASEAN-5 Countries. International Journal of Academic Research in Business and Social Sciences, 9(9), 359-373.

Copyright: (C) 2019 The Author(s)

Published by Human Resource Management Academic Research Society (www.hrmars.com)

This article is published under the Creative Commons Attribution (CC BY 4.0) license. Anyone may reproduce, distribute, translate and create derivative works of this article (for both commercial and non-commercial purposes), subject to full attribution to the original publication and authors. The full terms of this license may be seen at: http://creativecommons.org/licences/by/4.0/legalcode

\section{Vol. 9, No. 9, 2019, Pg. 359 - 373}

Full Terms \& Conditions of access and use can be found at http://hrmars.com/index.php/pages/detail/publication-ethics 


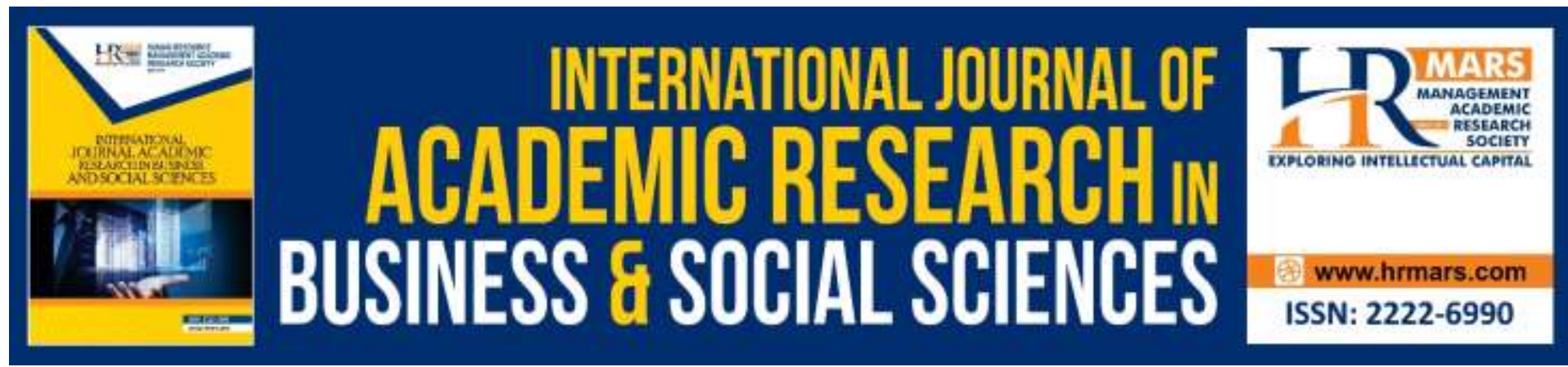

\title{
Information and Communication Technology (ICT) and Income Inequality in ASEAN-5 Countries
}

\author{
Amy Huong Yong Jing, Rossazana Ab-Rahim \& Farhana Ismail \\ Faculty of Economics \& Business, Universiti Malaysia Sarawak, Malaysia.
}

\begin{abstract}
Digital transformation spreads across borders, globalization develops or transforms the economics growth of a nation. Information and communication technology (ICT) fosters the economy; however, it might trigger the income inequality of a country. On this note, income inequality in ASEAN country is relatively higher than other countries. The aim of this study is to examine the relationship between ICT and income inequality in ASEAN-5 countries over the study period of 2009 to 2017. Employing panel data estimation method, the results show volume of internet users is found to have the strongest effect on income inequality among the ICT indicators. The findings suggest countries to focus on the innovation of ICT especially on the internet users, mobile cellular subscription and fixed telephone subscription to achieve economic growth and hence reduce income inequality. Investments in ICT infrastructure promote ICT technology cooperation as well as the expansion of ICT especially on the network access to confront with the income inequality.
\end{abstract}

Keywords: Information and Communication Technology, Economic Growth, Income Inequality, ASEAN-5

\section{Introduction}

Information and Communication Technology (ICT) acts as a backbone of technology growth and development of a nation. ICT is an important pillar for a country to gain the competitive advantage on the development of a country (Seki, 2008). ICT is useful to enable a firm to increase the productivity and profit and it facilitates the increase of the individual and household income (Spiezia, 2012). However, ICT growth may mitigate income inequality due to the contribution of ICT to economic growth offers many approaches to combat poverty (Roller \& Waverman, 2001).

Income inequality refers to the uneven distribution of income in a population. Decrease in income inequality will contribute to the economic growth according to Organization for Economic Cooperation and Development. This is because in societies with high income inequality many may suffer from high poverty, high crime rates, poor public health and low education level (Birdsong, 2015). This will harm the economic growth of a country. Thus, income inequality is an important issue to overcome to boost the economic growth in the country. 
Digital transformation growth should be understood as two simultaneous processes which involve technology evolution ahead to diffusion. For example, the innovation of telecommunication networks, computer technologies, software engineering and its spillover effects on network based used (Qiang, Rossotto \& Kimura, 2009). ICT fosters the economic growth in the country (Czernich et al. 2011). In a traditional trade, the setting of the production and consumption are separated across international borders. The efficient usage of the high-tech input devices will increase the supply and demand in the market.

ICT is important to enhance the growth in a country and it has been focus in various policies of ICT innovation. The importance of ICT-focus has been attributed to several converging factors such as the development of the use of the Internet as a means by which information is disseminated and through which communication and connectivity is enabled. The capability of the workers due to changes in new technology as well as the effect of ICT innovation on income inequality will greatly influence the growth in the country. ICT fosters the economic growth. As a result, poverty rate will decline in the country.

ASEAN with its strong and vibrant economy, ICT innovation, ongoing economic integration and demographics strategically located laid its foundation to become global leader in economy. Innovation of ICT in the economy has received much attention from the government of ASEAN countries, businesses and regional bodies. Embracement of ICT in ASEAN significantly increased since year 2015 till now. According to Kearney and Axiata (2016), targeting on the economic growth especially on GDP is the forefront goals of ASEAN countries.

Countries that are blessed with the success of ICT innovation will eventually boost its economic performance. ASEAN economy contributed $\$ 150$ billion in revenue in year 2015 with the connectivity and online services as the biggest components accounted $35 \%$ to $40 \%$ of overall revenue (Kearney and Axiata, 2016). ASEAN-5 digital population with its total number of populations, Internet users, social media users, mobile users and mobile social media users connection as shown in Table 1 below. 
Table 1: ASEAN-5 Digital Population 2018 (million)

\begin{tabular}{lccccc}
\hline Country & Population & Internet Users & $\begin{array}{c}\text { Social } \\
\text { Media Users }\end{array}$ & Mobile Users & $\begin{array}{c}\text { Mobile } \\
\text { social Users }\end{array}$ \\
\hline Singapore & 5.75 & 4.83 & 4.8 & 4.71 & 4.3 \\
Thailand & 69.11 & 57 & 51 & 55.56 & 46 \\
Indonesia & 265.4 & 132.7 & 130 & 177.9 & 120 \\
Malaysia & 31.83 & 25.08 & 24 & 21.62 & 22 \\
Philippines & 105.7 & 67 & 67 & 61 & 62 \\
\hline
\end{tabular}

Source: Southeast Asia Digital, Social and Mobile (2018)

Table 1 shows internet users depict the highest in Indonesia as its population is on the top of ASEAN with the digital users in Singapore is the lowest. In macroeconomic, the expansion of ICT to the economy trends held the potential of new sources of productivity opportunities. The expansion of ICT has a promising potential to generate foreign exchange earnings as well as job opportunities.

Particularly, Singapore embarked on its modernization program in the late 1960 s and 1970s mainly on its manufacturing industry. In 1960s, Singapore put in the effort to develop human capital under the Ministry of Trade and Industry. It provides the base foundation for Singapore to expand its economy in year 2012 onwards. In the context of ICT innovation in ASEAN, Singapore is the headway in realizing the e-commerce expansion in the economy. For example, Singapore's Olam International promoted smart farming through new technology while technology presence of ride-sharing services through a mobile application like Uber, Grab and GO Jek. Thailand open door policy focuses on its economic policy on trade and services sectors in ASEAN via ASEAN Framework Agreement on Services (AFAS) during the $5^{\text {th }}$ ASEAN Summit in Bangkok in year 1995. According to Koedrabreun and Raviwongse (2002), $50 \%$ of their samples showed that Internet users are very interested in using online transactions facilities. Indonesia had a slow growth in ICT in the past decades. The legal infrastructure of e-commerce in Indonesia is based on its Electronic Information and Transaction Act 2008. Indonesia has made significant progress in ICT. There was an increasing trend where Internet penetration in Indonesia had increasing throughout the years. Next, in Malaysia, Joint Advanced Integrated Networking (JARING) was connected to the Internet in year 1992 followed by TMNET in Malaysia in year 1996 (Adeline, Ali \& Hishamuddin, 2006).

Additionally, Multimedia Super Corridor Malaysia (MSC Malaysia) was launched under the tenure of the fourth Prime Minister, Tun Dr Mahathir Mohammad to facilitate the evolution of knowledge-based nation in Malaysia. During Malaysia Plan (2006-2010), cyber network expanded while the sector continued its growth during the $10^{\text {th }}$ Malaysia Plan (2011-2015). ICT successfully contribute to economic growth in Malaysia under the $11^{\text {th }}$ Malaysia Plan. Besides, Philippines enjoy the fastest ICT growing trend and was once branded as the fastest 
growing Internet population country. Before year 1928, telecommunication in Philippines was limited. By then, an American-owned Philippine Long Distance Telephone Company (PLDT) was established and bought by Ramon Cojuangco, a local Philippines man. First cellular telephone network was introduced in year 1993 under the Department of Science and Technology and Industrial Research Foundation in a project called Philnet Project (PHNET). First Internet connection in Philippines enabled Internet services such as email. E-commerce in Philippines played a tremendous potential in growth. The adaptation of online shopping trends with the rising of Internet users projected to reach USD-million in year 2018. Philippines is expected to become the fastest growing economy among ASEAN-5 in 2018 as stated by First Metro president Rabboni Francis Arjonillo (Rapper, 2018).

There is hesitation arises from the relationship between ICT and income inequality. ICT development plays a significant role to create more job opportunity and increase the economic growth of a country and act as a major contributor to poverty alleviation. Previous research claimed that ICT affects the income inequality too. Therefore, the general objective of this study is to examine the relationship between Information and Communication Technology (ICT) and income inequality in ASEAN-5 countries. There is limited research done based on income inequality especially in ASEAN countries. Most of the existing literatures based on intensive country studies and make it difficult to draw a comparative conclusion as the result is mixed. ICT has received comparatively little attention in the current globalization wave. As far as this study is concerned, existing studies focusing on income inequality in ASEAN countries appear to be limited. Past studies such as Richmond and Triplett (2016) examined the relationship between ICT and income inequality of 107 foreign countries while Yilmaz et. al (2018) investigated the impact of ICT penetration on poverty which involved 182 foreign countries. This represents an important gap in considering the relationship between ICT and income inequality in ASEAN countries. On this note, this study aims to investigate the nexus between various ICT services and income inequality of ASEAN countries. This study serves as a beneficial reference for the researchers and academician to explore an effective way to improve the contribution of different ICT services. Hence, this study can be a useful reference tool for policy makers, academician and government in the decision making. Next section offers the theoretical motivation with the empirical evidence on the issue of ICT and income inequality follows by the data and methodology sections. Empirical results will be presented in the subsequent section and lastly about the conclusion and future research direction of the study.

\section{Literature Review}

Kuznets hypothesized that market force first increased when the economy grows and hence affected on income inequality in his theory. In early development, investment opportunities are considerably high for those who have extra investment capabilities and they will increase their wealth even more. As for those people who are working from the rural area, they might be held down wages widening the income gap (Moffatt, 2019). Kuznets found that in underdeveloped countries and most of the developed countries, income distributed within traditional sector is less than income in the modern sector (Ganaie \& Kamaiah, 2015). Human capital accrual of the incurred cost takes place of the accrual of human capital as the main source of growth in a mature economy. An inequality usually slows down the economic growth as the education levels lower especially for the poorer people. Kuznets (1955) found 
that the income inequalities are higher in developing country compared to those in developed country. He believed inequality would follow an inverted U-shape that it rises before then falls with the increase of income per capita.

In the viewpoint of endogenous theory, the technological progress is being described as an endogenous variable where it is based on constant return to scale for capital. Technological development in this model is considered as a public good that government can cause affect to the growth rates (Ugur, 2016). The Schumpeter model explained the process of production, dynamic analysis of the economy, trends of growth and the demise of capitalism. It is all about the growth generated by innovations, innovations result from entrepreneurial investment and the replacement of new technology. Schumpeter said the entrepreneur is one of the new production factors depend on technical and technological economy condition for example like ICT innovation where it possess the cyclical fluctuation in market. Economy will expand in the market. Sometimes, growth can be described as with a create destruction when inequality problems exist.

The spread of ICT may increase or decrease income inequality within a country. Parham (2004) described ICT-driven growth in his study based on the adoption of ICT. The contribution of ICT to economic growth offers many approaches to combat poverty and hence positively affecting both social and human capital through economic development (Roller \& Waverman, 2001). ICT is useful to enable a firm to increase the productivity and profit and it facilitates the increase the individual and household income (Spiezia, 2012). The positive network effect is considered important from ICT (Bansler \& Havn, 2002) that the technological change exemplified by ICT enhances the competition in the market. Technological change might disrupt the original market wealth concentration (Latzer, 2009). According to Tong and Dall'erba (2008), there is a positive result between ICT and income inequality in China. During the rapid growth of developing in the country at study year range, ICT's industry in China is facing challenges. One major concern will be the uneven distributed of ICT growth especially based on the number of Internet users and such disparities rise up the inequalities in income and opportunities especially in a developing country. Similar studies done showed ICT is positively correlated with wage inequality. (lacovone \& Pereira-Lopez, 2018). Both highskilled worker and low-skills workers receive higher wages in more ICT-progressive industries than non-ICT-progressive industry causing more income inequality problems. Thus, ICT might positively relate to income inequality. The results are mixed.

\section{Data and Methodology}

The data sets for the dependent variable, independent variables and control variables are obtained from the World Bank Group and Telecommunication Union. This study exploits the secondary panel data of the ASEAN-5 namely Singapore, Thailand, Indonesia, Malaysia and Philippines over a period of 2003-2017.

To capture the effect of ICT towards income inequality, Richmond and Triplett (2016) examined the relationship between ICT and income inequality from a cross-national perspective which involved 107 countries. This study complements the reviews the relationship of the explanatory variables such as volume of Internet users $\left(X_{1}\right)$ in million, mobile cellular telephone subscription $\left(X_{2}\right)$ in million, fixed broadband subscription $\left(X_{3}\right)$ in million and fixed telephone subscription $\left(X_{4}\right)$ in million with ASEAN-5 income inequality as the 
dependent variable represents by Gini Coefficient (Richmond \& Triplett, 2016). In order to clearly identify the relationship between independent variables and dependent variable, control variables being included such as the demographic factors, crude birth rate per 1000 people, total population aged 65 and above measured in percentage of total and the percentage of urbanization rate. Richmond and Triplett (2016) used these factors as the control in their study where these variables are expected to be correlated with my outcomes. The specific relationship it may contaminate the results. Thus, it is important to include control variables in the model.

Generally, there are three ways to estimate a model based on the assumption made. Firstly, Pooled Ordinary Least Squares (POLS) assumes the intercept as constant over airline (Gujarati \& Porter, 2009). Fixed Effect Model (FE) and Random Effect Model (RE) are one of the ways though. Panel data models examine the individual-specific effects, time effects to deal with heterogeneity or individual effect either fixed or random effect. Hausman test is used to test the endogeneity in the explanatory variables to test whether fixed or random effect model is appropriate (Sheytanova, 2014). Hausman statistic is computed as:

$$
W=\left(\beta_{f e}-\hat{\beta}_{r e}\right)^{\prime}\left(\hat{\Sigma}_{f e}-\hat{\Sigma}_{r e}\right)\left(\beta_{f e}-\hat{\beta}_{r e}\right)
$$

where and are estimated covariance matrix for FE and RE models respectively. It is a test for the independence of $\mu \mathrm{i}$. It means FE and RE are both consistent, but somehow FE is inefficient. On the contrary, if there is correlation, $F E$ is consistent and $R E$ is inconsistent. If $W$ is insignificant, RE estimator model is relevant when null hypothesis is accepted. It means Hausman statistic is bigger than its critical value. If null hypothesis is rejected, a FE model is favorable.

Fixed effect (FE) model is a statistical model to control the omitted bias when there is an unobserved individual-specific factor found to be correlated with the dependent variable. Advantage of FE model is that it can deal with unobserved heterogeneity. FE model for $k$ factors can be expressed in following way:

$$
y_{i t}=\alpha_{i}+\beta_{1} x_{1, i t}+\ldots+\beta_{k} x_{k, i t}+\varepsilon_{i t}
$$

where no overall intercept included in the model in which $\alpha_{i}$ is unique and unknown intercept for each individual unlike constant term $\left(\beta_{0}\right)$ in Model (1.2) while the slopes ( $\beta$ parameters) are same for all individuals with the assumptions that are valid for FE model (Sheytanova, 2014). FE models always gives consistent results for estimate but it is inefficient compare to RE model estimates. Specification of model as below:

$$
\begin{aligned}
Y I_{i t}= & \beta_{0}+\beta_{1} V O I U_{1, i t}+\beta_{2} M C T_{2, i t}+\beta_{3} F B_{3, i t}+\beta_{4} F T_{4, i t}+\beta_{5} C B_{5, i t}+\beta_{6} P A_{6, i t}+ \\
& \beta_{7} U R_{7, i t}+\varepsilon_{i t}
\end{aligned}
$$

where $\mathrm{YI}$ represents income inequality as the dependent variable. VOIU is the volume of internet users, MCT represents the mobile-cellular telephone subscription, FB represents fixed broadband subscription while FT denoted by fixed telephone line subscription. The controlling variables are $\mathrm{CB}$, crude birth; $\mathrm{PA}$, total population aged 65 and UR, urbanization rate. After that, the model will be tested through Skewness/Kurtosis normality tests to ensure variables are normally distributed and diagnostic tests which consist of White test, Wooldridge test and Variance Inflation Factor (VIF) to ensure the goodness of fits in the model. 


\section{Results and Discussion}

The results are presented in Table 2 below.

Table 2: Results of POLS, RE AND FE Data Analysis

\begin{tabular}{|c|c|c|c|}
\hline & Pooled OLS & Random Effect & Fixed Effect \\
\hline Constant & $\begin{array}{l}3.8267 \\
(19.17) * * *\end{array}$ & $\begin{array}{l}3.8267 \\
(19.17)^{* * *}\end{array}$ & $\begin{array}{l}4.1924 \\
(16.9)^{* * *}\end{array}$ \\
\hline IVOIU & $\begin{array}{l}0.0092 \\
(1.65)\end{array}$ & $\begin{array}{l}0.0092 \\
(1.65)^{*}\end{array}$ & $\begin{array}{l}-0.0002 \\
(-0.03)\end{array}$ \\
\hline IMCT & $\begin{array}{l}-0.0280 \\
(-1.35)\end{array}$ & $\begin{array}{l}-0.0280 \\
(-1.35)\end{array}$ & $\begin{array}{l}0.0527 \\
(1.43)\end{array}$ \\
\hline IFB & $\begin{array}{l}0.0114 \\
(1.03)\end{array}$ & $\begin{array}{l}0.0114 \\
(1.03)\end{array}$ & $\begin{array}{l}-0.0097 \\
(-0.64)\end{array}$ \\
\hline IFT & $\begin{array}{l}-0.3868 \\
(-2.37)^{* *}\end{array}$ & $\begin{array}{l}-0.3868 \\
(-2.37)^{* *}\end{array}$ & $\begin{array}{l}-0.0263 \\
(-0.92)\end{array}$ \\
\hline ICB & $\begin{array}{l}0.0536 \\
(0.99)\end{array}$ & $\begin{array}{l}0.0536 \\
(0.99)\end{array}$ & $\begin{array}{l}-0.0669 \\
(-0.74)\end{array}$ \\
\hline PA & $\begin{array}{l}-0.0068 \\
(-0.97)\end{array}$ & $\begin{array}{l}-0.0068 \\
(-0.97)\end{array}$ & $\begin{array}{l}-0.0037 \\
(-0.39)\end{array}$ \\
\hline UR & $\begin{array}{l}-0.0011 \\
(-1.57)\end{array}$ & $\begin{array}{l}-0.0011 \\
(-1.57)\end{array}$ & $\begin{array}{l}-0.0067 \\
(-3.09) * * *\end{array}$ \\
\hline Hausman test & - & $\begin{array}{l}11.63 \\
(0.1134)\end{array}$ & \\
\hline Breush-Pagan LM test & $\begin{array}{l}0.00 \\
(1.0000)\end{array}$ & & \\
\hline Observations & 75 & 75 & 75 \\
\hline
\end{tabular}

Note: ${ }^{*}, * *$ and $* * *$ indicate the respective $10 \%, 5 \%$ and $1 \%$ significance level

The results for POLS model and RE model are quite similar in term of coefficient value. What differs them is the significance level of the variables. For the POLS model, there is an independent variable significant at $5 \%$ significance level which is fixed telephone line subscription (IFT). As for RE model, there is an independent variable significant at $10 \%$ of significance level which is the volume of internet users (IVOIU) and fixed telephone line subscription (IFT) significant at $5 \%$ significance level. As for FE model, there is an independent variable significant at $1 \%$ significance level which is the control variable, urbanization rate (UR). Under Hausman null hypothesis tested, p-value shows 0.1134 which is larger than 0.05 . $\mathrm{H}_{0}$ is not rejected. Random Effect (RE) model is appropriate. Next, under Breush-Pagan LM null hypothesis tested, $\mathrm{p}$-value shows 1.000 which is larger than $0.05 . \mathrm{H}_{0}$ is not rejected. Pooled Ordinary Least Square (POLS) model is appropriate. Hence, Pooled Ordinary Least Square (OLS) is being used as the final model.

The model being tested whether the variables are normally distributed or abnormally distributed and the results are shown in Table 3 . The results show that $\mathrm{P}$ - value (Prob. ChiSquare) is 0.2980 which is more than 5 percent significance level, $\alpha=0.05$. Thus, $H_{0}$ fails to 
reject and it means that the null hypothesis of variables is normally distributed in the model is being accepted.

Table 3: Skewness/Kurtosis Tests Results

\begin{tabular}{lc}
\hline Skewness & 0.7352 \\
Kurtosis & 0.1360 \\
Prob. Chi-Square & 0.2980 \\
Observation & 75 \\
\hline
\end{tabular}

The POLS model is written as,

$$
\begin{aligned}
l Y I_{i t}= & 3.8267+0.0092 \log \text { VOIU } U_{1, i t}-0.0279 \log M C T_{2, i t}+0.0114 \log F B- \\
& 0.0387 \log F T+0.0536 \log C B_{5, i t}-0.0068 P A_{6, i t}-0.0011 U R_{7, i t}+\varepsilon_{i t}
\end{aligned}
$$

$\beta_{0}$ is the intercept of the model, which is 3.8267. $\beta_{1}$ is the coefficient of volume of online users, which is 0.0092 . An increase in the volume of internet users of $1 \%$, on average, leads to the rise in income inequality by $0.0092 \%$. There is a positive relationship between the volume of online user and income inequality which is different from our negative prediction before because in a broader Internet ecosystem, quality improvements are very important to face the challenges to measure the aggregate effects of the Internet at aggregate level (Corrado \& Van Ark, 2016). $\beta_{2}$ is the coefficient of mobile-cellular telephone subscription, which is -0.028. An increase in mobile-cellular telephone subscription of $1 \%$, on average, leads to a decrease in income inequality by $0.028 \%$. As being one of the ICT measures, the mobile phone has a significant negative effect on income inequality. The mobile phone is less costly compared to an earlier time. It is commonly being used widely in the population nowadays. Thus, the increase in mobile technology users will decrease income inequality (Richmond \& Tripplett, 2016). $B_{3}$ is the coefficient of fixed broadband subscription, which is 0.0114 . An increase in fixed broadband subscription of $1 \%$, on average, leads to an increase in income inequality by $0.0114 \%$. Fixed broadband subscriptions are costlier in general to an individual or onto a network. As one of the ICT measures, fixed broadband has a significant positive effect on income inequality, which the effect is considered largest among other ICT measures (Richmond\& Triplett, 2016). However, the effect might not appear consistently within the lowest-income-countries because ICT has yet to reach the sufficient thresholds of access in order to affect the aggregate income distribution. $\beta_{4}$ is the coefficient of fixed telephone line subscription, which is -0.0388 . An increase in fixed telephone line subscription of $1 \%$, on average, leads to a decrease in income inequality by $0.0388 \%$. One of the examples in India, telephone line subscription reached the rural area via the introduction of Public Call Offices (PCOs) to support the poverty-reducing strategies. Besides, the increase in the penetration rate of fixed telephone raise GDP per capita by $0.45 \%$ (Roller \& Waverman, 2001) and hence reduce income inequality.

The relationship between ICT independent variables and income inequality is explained by Kuznets theory. Generally, the study found that there is negative relationship between dependent variable income inequality in ASEAN-5 ( $\mathrm{Yl}_{\mathrm{it}}$ ) with ICT independent variables; mobile-cellular telephone subscription (IMCT), fixed telephone line subscription 
(IFT) and positive relationship with volume of internet users (IVOIU) and fixed broadband subscription (IFB). The crude birth rate, total population aged 65 and above and urbanization rate are being included as control variables in the study. From the results computed, only one ICT independent variable is significant at $5 \%$ of significance level which is fixed telephone line subscription (IFT).

Table 4: Goodness of Fit Tests Results

\begin{tabular}{lc}
\hline Heteroscedasticity & 60.26 \\
(White test-chi stat) & $\mathbf{( 0 . 0 0 5 ) * * *}$ \\
Serial Correlation & 4.228 \\
(Wooldridge test- F stat) & $(0.1089)$ \\
Multicollinearity & 6.57 \\
(mean VIF) & \\
\hline
\end{tabular}

Note: $* * *$ indicates $1 \%$ significance level

The heteroscedasticity result show that P-value (Prob. Chi-Square) is 0.005 which is lower than 5 percent significance level, $\alpha=0.05$. Thus, $\mathrm{H}_{0}$ is rejected and it means that the null hypothesis of homoscedasticity in the model rejected where the variances are not constant in the model. The multicollinearity result show that P- value (Prob. F stat) is 0.1089 which is higher than 5 percent significance level, $\alpha=0.05$. Thus, $\mathrm{H}_{0}$ fail to reject and it means that the null hypothesis of no serial correlation in the model is being accepted. Based on the assumption of $10<$ VIF $<0.1$ where the result shows the mean VIF is 6.57 , it means there is no multicollinearity problems between independent variables. Hence, heteroscedasticity occurred in the model. So, the model needs to be corrected.

Table 5: Results of Corrected POLS Data Analysis

\section{Pooled OLS}

\begin{tabular}{ll}
\hline Constant & 3.8267 \\
& $(\mathbf{1 3 . 8 6})^{* * *}$ \\
IVOIU & 0.0092 \\
& $(\mathbf{3 . 0 6})^{* * *}$ \\
IMCT & -0.0280 \\
& $(\mathbf{- 1 . 7 6 ) *}$ \\
IFB & 0.0114 \\
& $(1.19)$ \\
IFT & -0.3868 \\
& $(-2.21)^{* *}$ \\
ICB & 0.0536 \\
& $(0.77)$ \\
PA & -0.0068 \\
& $(-0.67)$ \\
UR & -0.0011 \\
& $(\mathbf{- 1 . 8 5 ) *}$ \\
\hline
\end{tabular}

Note: $*, * *$ and $* * *$ indicate the respective $10 \%, 5 \%$ and $1 \%$ significance level 
Unlike the POLS model before correction for heteroscedasticity problem, there is only one independent variable significant at $5 \%$ significance level which is fixed telephone line subscription (IFT). For corrected POLS model, there are two independent variables significant at $10 \%$ significance level which are mobile-cellular telephone subscription (IMCT) and control variable, urbanization rate (UR). There is an independent variable significant at $5 \%$ significance level which is fixed telephone line subscription (IFT). Besides, there is an independent variable significant at $1 \%$ significance level which is the volume of internet users (IVOIU). There are more variables significant at $5 \%$ and $1 \%$ significant level.

\section{Conclusion}

This study examines the relationship between ICT and income inequality in ASEAN-5 countries overt the study period of 2003 - 2017. The results of this study show the relationship between ICT and income inequality in ASEAN-5 countries is positive; whereby the volume of internet users in ASEAN-5 countries has significant positive effect on income inequality. On this note, mobile-cellular telephone subscription (IMCT) and urbanization rate (UR) are found to have the positive relationship with the economic growth. Fixed telephone line subscription (IFT) is significant at $5 \%$ significance level and volume of internet users (IVOIU) is significant at $1 \%$ significance level. The most significant factor among the ICT independent variables that influence income inequality is volume of internet users, which is 0.009 with its $p$-value, 0.003 . An increase $1 \%$ in volume of internet users, on average, leads to increase in income inequality by 0.009 . The results imply that ICT does affect income inequality in ASEAN-5 countries. Hence, ICT development should be considered in future policies to combat income inequality in ASEAN countries

Panel data models examine the individual-specific effects, time effects to deal with heterogeneity or individual effect either fixed or random effect. Under Hausman and BreushPagan LM null hypothesis tested, Pooled Ordinary Least Square (OLS) being used as the final model. This study employs panel estimation method. However, the results follow the time series characteristic. Unbiased and consistent parameters being derived even the time constant attributes are present from year 2003 to year 2017. It is proven that the model has a "time series of cross sections" which do not necessarily refer to the same unit and no universal effects across time. POLS is said to be consistent if the vector of time-variable factors uncorrelated with the individual effect for examples, unobserved and time-invariant heterogeneity it will cause serial correlation (Aquaro, 2016). However, there is no serial correlation in this model as being tested. Hence, the model is valid.

From this research, it can be concluded that ASEAN-5's outstanding performance in economic growth can be traced to the policy formation to combat poverty through ICT. There are few key roadblocks between ASEAN and an advanced economy, these includes weak business broadband built-out, inhibitive regulations on innovation for mobile financial services, lack of single digital market and weak local ICT infrastructure system, which pose negative impact on economic growth of a country and leads to income inequality in the country.

ICT development especially in network service coverage including investments in ICT infrastructure, policies in ICT investment, international ICT technology cooperation are necessary to combat income inequality in ASEAN-5 countries. By focusing on economic growth through ICT in line with the vision of Interconnected world with International 
Telecommunication Union (ITU), ASEAN countries can aim to achieve global top economies within the next decade.

Acknowledgement: This work was supported by Universiti Malaysia Sarawak [grant numbers F01/SpMYRA/1676/2018].

\section{References}

Adeline, C. P. H., Ali, K., \& Hishamuddin, I. (2006). E-Commerce: A Study on Online Shopping in Malaysia. Journal of Social Science, 13(3). 231-242.

Aker, J. C. (2008). Does Digital Divide or Provide? The Impact of Cell Phones on Grain Markets in Niger. Job Market Paper. Retrieved from:

https://www.cgdev.org/sites/default/files/archive/doc/events/2.12.08/Aker_Job_M arket_Paper_15jan08_2.pdf

Aquaro, M. (2016). Topics in Microeconometrics Panel Data Methods. University of Warwick. Retrieved from:

https://warwick.ac.uk/about/london/study/warwick-summerschool/courses/econometrics/aquaro_wess_lecture1_slides.pdf

ASEAN. (2015). ASEAN ICT Masterplan 2015 Completion Report. Retrieved from: https://www.asean.org/storage/images/2015/December/telmin/ASEAN\%20ICT\%20 Completion\%20Report.pdf?fbclid=IwAR2EOmwX_UoA4fqtiUtKnApLK1BAigovol88Mu nfDG7olTQMSi8fnMCCqEo

ASEAN-Canada Research Partnership Working Paper Series Working Paper No. 1. (2014, April). Income Inequality in ASEAN: Perceptions on Regional Stability from Indonesia and the Philippines.

Bansler, J. P. \& Havn, E. (2002). Exploring the Role of Network Effects in its Implementation: The Case of Knowledge Management Systems, 817-829.

Birdsong, N. (2015, February 5). The Consequences of Economic Inequality. Retrieved from: https://sevenpillarsinstitute.org/consequences-economic-inequality/

Breusch, T. S., \& Pagan, A. R. (1980). The Lagrange Multiplier Test and its Applications to Model Specification in Econometrics. The Review of Economic Studies, 47(1), 239.

Corrado, C. \& Ark, V. B. (2016). The Internet and productivity. Handbook on the Economics of the Internet, 120-145.

Czernich, N., Falck, O., Kretschmer, T. \& Woessmann, L. (2011). Broadband infrastructure and economic growth. The Economic Journal, 121, 505-532.

Dell'Anno, R., \& Solomon, H. O. (2014). Informality, Inequality, and ICT in Transition Economies. Eastern European Economics, 52(5), 3-31.

Ganaie, A. A. \& Kamaiah, B. (2015). Kuznets Inverted U Hypothesis of Income Inequality: Looking Inside the Available Economic Literature. SSRN Electronic Journal. doi:10.2139/ssrn.2591284

Gujarati, D. N. \& Porter, D. C. (2009). Basic Econometric. United States: McGraw-Hill.

lacovone, L. \& Lopez, M. D. L. P. P. (2018). ICT Adoption and Wage Inequality: Evidence from Mexican Firms. World Bank Policy Research Working Paper, 8298

International Telecommunication Union. (2017). World Telecommunication/ICT Indicators Short Questionnaire 2017. Retrieved from ITU website: https://www.itu.int/en/ITUD/Statistics/Documents/datacollection/ITU_SQ_2017.pdf 
Kearney, A. T. \& Axiata. (2016). The ASEAN Digital Evolution. Retrieved from http://www.southeast-asia.atkearney.com/documents/10192/6986374/ASEAN+ Digital+ Revolution.pdf/86c51659-c7fb-4bc5-b6e1-22be3d801ad2

Koedrabreun, P \& Raviwongse, R. (2002). A Prototype of Retail Internet Banking for Thai Customers. Scuola Superiore Guglielmo Reissi Romoli (SSGRR). Retrieved from http://citeseerx.ist.psu.edu/viewdoc/download?doi=10.1.1.467.9042\&rep=rep1\&typ $\mathrm{e}=\mathrm{pdf}$

Kuznet. (1955). Economic Growth and Income Inequality. The American Economic Review, 45(1), 1-28

Latzer, M. (2009). Information and communication technology innovations: radical and disruptive? New Media \& Society, 11(4), 599-619. doi:10.1177/1461444809102964

Moffatt, M. (2019). Essential Economics Terms: Kuznets Curve. Retrieved from ThoughtCo https://www.thoughtco.com/kuznets-curve-in-economics-1146122

Parham, D. (2004). Sources of Australia's Productivity Revival. Economic Record, 80(249), 239-257. doi:10.1111/j.1475-4932.2004.00175.x

Qiang, Z. W. C. \& Rossotto, Carlo, M. (2009). Economic Impacts of Broadband. Retrieved from World Bank Group website:

https://siteresources.worldbank.org /EXTIC4D/Resources/IC4D_Broadband_35_50.pdf

Rapper. (2018, January 5). Philippine economy to grow fastest in ASEAN-5 in 2018 - First Metro. Retrieved from The Public-Private Partnership (PPP) Center website: https://ppp.gov.ph/in_the_news/philippine-economy-to-grow-fastest-in-asean-5-in2018-first-metro/

Richmond, K. \& Triplett, R. E. (2016). ICT and income inequality: a cross-national perspective. International Review of Applied Economics. 32(2), 195-214. doi: 10.1080/02692171.2017.1338677

Roller, L. \& Waverman, L. (2001). Infrastructure and Economic Development: A Simultaneous Approach. American Economic Association. 91(4), 909-923. Retrieved from https://www.aeaweb.org/articles?id=10.1257/aer.91.4.909

Seki, Y. (2008). The Importance of ICT for the Knowledge Economy: A Total Factor Productivity Analysis for Selected OECD Countries. Papers of the Annual IUE-SUNY Cortland Conference in Economics in: Proceedings of the Conference on Emerging Economic Issues in a Globalizing World, (pp. 72-90). Izmir University of Economics.

Sheytanova, T. (2014, April 9). The Accuracy of the Hausman Test in Panel Data: a Monte Carlo Study. Orebro University. Retrieved from http://oru.diva-portal.org/smash/get/diva2:805823/FULLTEXT01.pdf

Shin, I. (2012). Income inequality and economic growth. Economic Modelling, 29(5), 20492057. doi:10.1016/j.econmod.2012.02.011

Southeast Asia digital, social and mobile 2018. (2018). Retrieved from ASEANUP website: https://aseanup.com/southeast-asia-digital-social-mobile/

Spiezia, V. (2012), ICT investments and productivity: Measuring the contribution of ICTS to growth OECD Journal: Economic Studies, (1). https://doi.org/10.1787/eco_studies2012-5k8xdhj4tv0t.

The United Nations Economic and Social Commission for Asia and the Pacific (ESCAP). 
(2018). Inequality in Asia and the Pacific in the era of the 2030 Agenda for Sustainable Development. Retrieved from https://www.unescap.org/publications/inequality-asia- and- pacific-era-2030agenda-sustainable-development

Tong, D. \& Dall'erba, S. (2008). Spatial Disparities in The Chinese ICT Sector: A Regional Analysis. Retrieved from https://pdfs.semanticscholar.org/dc80/16b5348f1e77b846f2b405855031a6f8f20e.p df?_ga=2.190932206.596395309.1552657243-37258961.1551509191

Trading Economics. (2019). Malaysia Birth Rate Crude Per 1000 People. Retrieved from Trading Economics website:

https://tradingeconomics.com/malaysia/birth-rate-crude- per-1-000-people-wbdata.html

Ugur, M., Trushin, E., Solomon, E., \& Guidi, F. (2016). R\&D and productivity in OECD firms and industries: A hierarchical meta-regression analysis. Research Policy, 45(10), 20692086. doi:10.1016/j.respol.2016.08.001

World Bank. (2019). GINI index (World Bank estimate). Retrieved from World Bank website: https://data.worldbank.org/indicator/SI.POV.GINI 